\title{
Attempt at profiling and regionalisation of COVID-19 vaccine campaigns in Poland - preliminary results
}

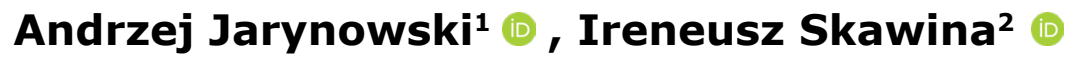

${ }^{1}$ Interdisciplinary Research Institute in Wrocław, Poland

${ }^{2}$ University of Social Sciences, Świdnica, Poland

\begin{abstract}
Background: Social attitudes and context have a fundamental impact on the COVID-19 vaccine acceptance. This issue will be challenging the existing Polish public health infrastructure during the planned immunisation program. Material and methods: We attempt to exemplify Poland-specific social background via causal diagram and regional factor analysis based on dimensions (epidemiological potential, ability to act, magical thinking, corona scepticism, information needs etc.) by December 2020 - shortly before vaccination started. Results: We identified several potential target subpopulations and provide possible regional classification. We distinguish clusters of regions where communication strategies should be taken into consideration: 1) extending campaign reach, common social goods and conformism; 2 ) individual's profits and misinformation blocking. Conclusions: We are signalling the need for profiling and regionalization in campaigns and propose possible starting points for protocols for various voivodeships when safe and effective vaccines are available in Poland.
\end{abstract}

Keywords: vaccine coverage $\cdot$ vaccine uptake $\cdot$ information campaigns $\cdot$ public health interventions $\cdot$ COVID-19

\section{Citation}

Jarynowski A, Skawina I. Attempt at profiling and regionalisation of COVID-19 vaccine campaigns in Poland - preliminary results. Eur J Transl Clin Med. 2021;4(1):13-21.

DOI: 10.31373/ejtcm/134674

\section{Introduction}

The National Anti-Covid Immunisation Programme announced on 08.12.2020 [1] involves a widespread, voluntary and free vaccination to take place in Poland in 2021. Discovery, delivery and logistics of candidates or soon available SARS-CoV-2 vaccines seem to be one of the biggest challenges in the history of medicine [2]. However, due to shortened clinical trials or conspiracy theories [3-4], the issue of vaccine acceptance arose in particular societies. According to the opinion polls and surveys [5-9], less than $50 \%$ of the Polish adult population are willing to undergo any kind of anti-coronavirus vaccination and the majority still remains undecided. In 
Poland, confidence in vaccines for other diseases is a little below EU average, however Poles less confident over time [10]. The Polish government plans to carry out a large information and pro-turnout campaign [1] but empirical research on the relationship between vaccination uptake intent and acceptance in various Polish subpopulations is necessary [11-12]. The willingness [13-15] of a given person to be vaccinated is a combination of various factors: rational (homo oeconomicus), such as efficacy vs. safety calculation, psychological (homo psychologicus), such as trust or cognitive dissonance, as well as normative factors (homo sociologicus), like cultural or socialization issues. Achieving high acceptance of immunization in the population is required in order to achieve a high coverage level needed to reach herd immunity [11]. This will be a complex challenge [16-17] necessitating collaboration among various stakeholders, e.g. medical scientists, communication researchers and marketers, social and cognitive scientists, policy makers, public health officials, NGOs and patient group representatives and health care workers.

\section{Material and methods}

Due to the lack of empirical evidence based on the Polish population [11], some analysts and experts in

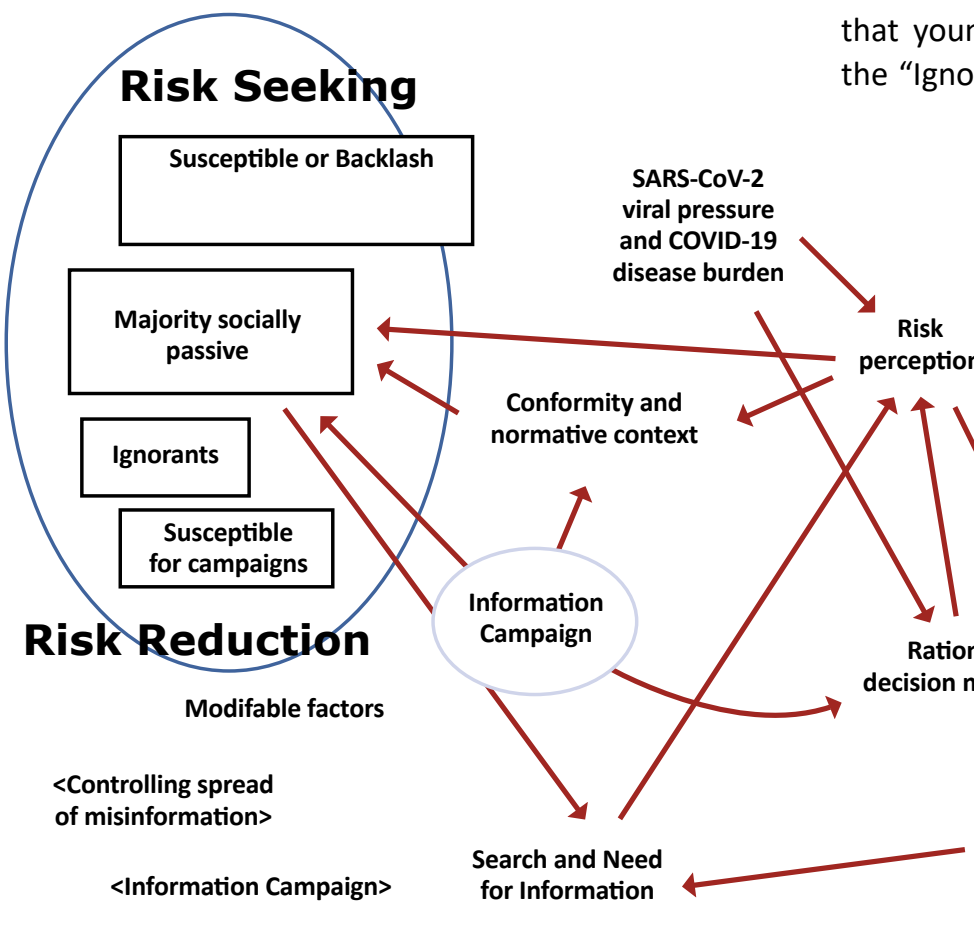

Figure 1. An attempt to use a causal diagram to describe the Polish social system with

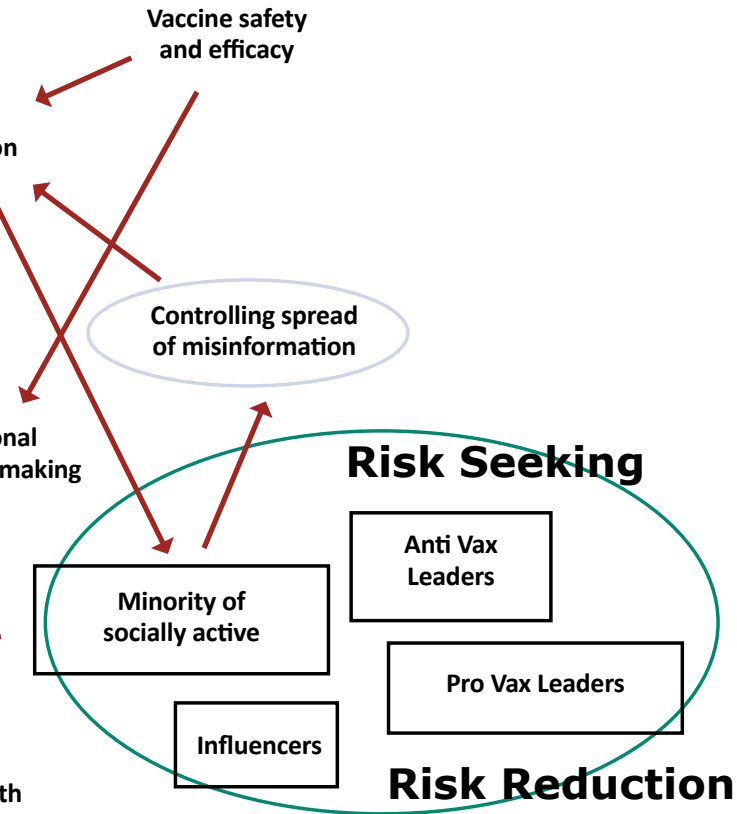

regard to vaccination amidst the pandemic. Rectangles are subpopulations (with its own composition of age, gender, place of residence, income, etc.), arrows indicate

main interactions, shadow variables are modifiable factors (information campaigns and controlling the spread of (mis)-information) 
nation Leaders" and the elderly among the "Susceptible to campaigns", populists among "Susceptible to backlash" [5, 26-28]. However, some further profiling is needed. It is especially noticeable with regard to populations previously marginalized in pandemic social studies [24-25], i.e. the Polish elderly (disproportionately affected by the COVID-19), who need adequate support and information networks concerning the vaccination, as well as immigrants, who might be facing language barriers [29]. These groups are especially hardly able to properly estimate the risk-benefit ratio related to vaccination, so reaching them and providing information will be a key influencing factor. Moreover, some topics and concerns based on other vaccination programs [30-38] and COVID-19 vaccine [5, 39-41] have been preliminarily mapped.

\section{Results}

To understand the ground for COVID-19 vaccine acceptance in Poland, let us consider the data available at the voivodeship level (NUTS-2). In the various theories of social action usually the common assumption is that one should distinguish attitudes (as well as opinions) and socio-epidemiological background (context) from the sphere of activity (actions). A given population may not be fully confident about the COVID-19 vaccine, but it could be not enough for an active refusal - for this, a fertile social environment is needed. For instance, the inhabitants of big cities declare skipping mandatory vaccination a few times more than the rest of the popula- tion [23]. A high fraction of people who were not convinced by immunisation and did not trust doctors, science or the government, were still agreeing to vaccination [21].

In order to operationalize the concepts of interest, let us try to define the following socio-epidemiological dimensions:

1. Corona scepticism - mean Google relative search volume (RSV) [42] 25.07-25.08.2020 (30 days) for phrases: "fałszywa pandemia" (false pandemic), "plandemia" (plandemic), "epidemia+ściema" (fake epidemic). The level of corona scepticism could be a proxy for susceptibility to backlash [43] (Fig. 1).

2. General_interest - interest of the general population in coronavirus by mean Google RSV [42] 25.07-25.08.2020 (30 days) for phrases: "koronawirus" (coronavirus), "zakażenia" (infections) and Coronavirus topic. To some extent, this measures information needs [11] with regard to the disease (Fig. 1).

3. Conspiracy_Theorists: Conspiracy Theories Potential is defined as an interest of the general population in various paranatural or conspiracy concepts by mean Google RSV [42] 08.12.2019-07.12.2020 (12 months) for phrases: QAnon, Kabala, UFO, as well as Horoscope and New World Order topics. Magical thinking [44] is known to anticorrelate with trust in vaccines [21] in Poland.

4. Cum_infections - Cumulative SARS-CoV-2 case notification number since the beginning of the epidemic until 8 XII 2020 per 5000 inhabitants [16].

5. Death_trend - Trend in the number of deaths de-

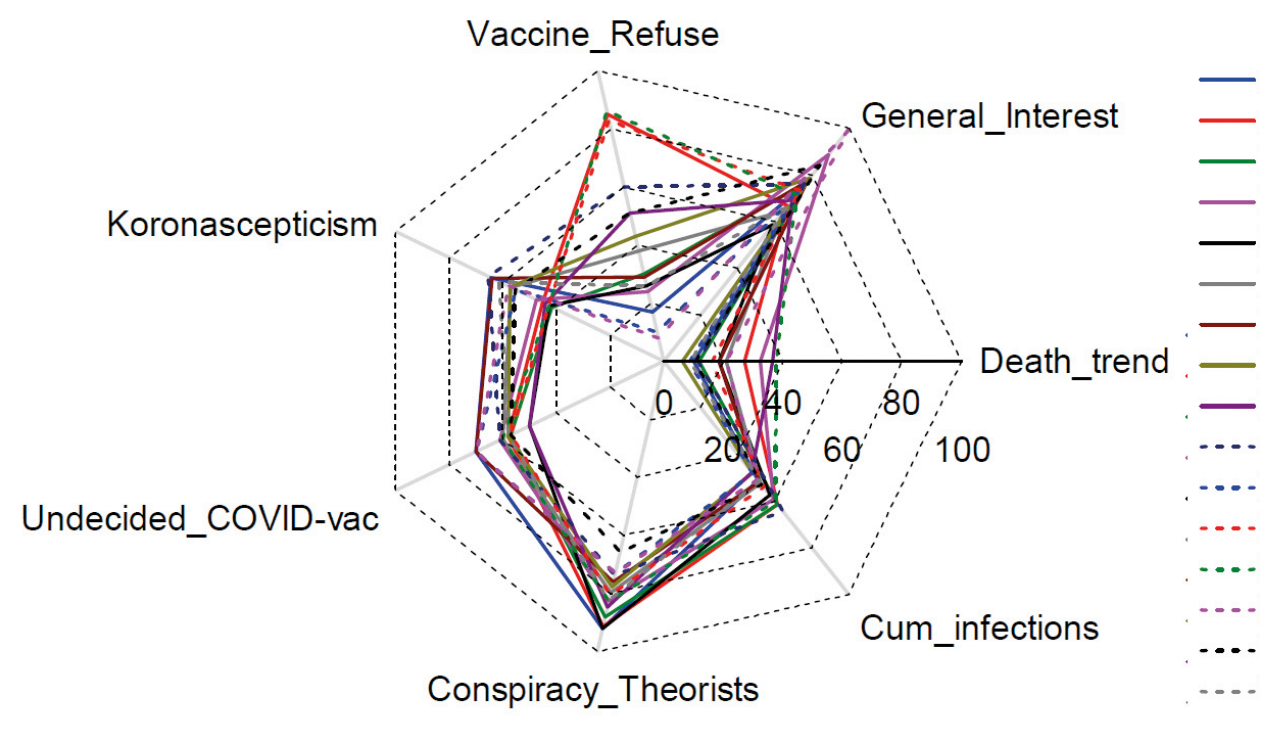

Figure 2. Radar graph of 7 chosen socio-epidemiological dimensions potentially related to willingness to COVID-19 vaccine uptake for the 16 Polish voivodeships 
fined as the trend coefficient of daily death case registry due to COVID-19 1 XI - 8 XII 2020 [19]. Experienced total viral pressure (point 4) and recent disease burden (point 5) known as epidemiological potential in local neighborhoods may infer risk perception $[45,14]$.

6. Vaccine_refuse - vaccination refusal rate [46] for non-medical reasons (per 10000 planned vaccination aged 0-19 in 2018). This could be a proxy of potential ability to act.

7. Undecided_COVID-vac - percentage of respondents who in the Kantar survey [8] (mid October 2020) did not declare willingness to undergo vaccination against COVID-19 (on a macroregion NUTS-1 level only). It is a proxy of the size of subpopulation which could be susceptible to campaigns (Fig. 1).

Negative attitudes towards childhood immunisation according to surveys performed 2009 by voivodeship [47] anticorrelated with vaccine refusal rate, which suggest dissonance between attitude and action. It is worth noting that these dimensions may be defined in a different manner and many other dimensions could be added. Moreover, epidemiological potential and general interest (Fig. 1, 2) are highly temporal variables, so a longitudinal approach would be prefered as we have already seen that our observables are changing in time [48].

\section{Discussion}

We attempt to systematize geographical diversity by factor analysis. In this simplified approach we do not assume any weights and all 7 dimensions are considered as equal predictors of attitude towards COVID-19 vaccine.

Geographical differences (Tab. 1) could be utilized in a dedicated communication practice $[45,49]$ :

- Factor 1 - regions with a low potential for action but with a high rate of undecided people. Recommended communication strategy should consider improving the reach of campaigns with emotionally-oriented content referring to conformism and common good [50].

- Factor 2 - regions that can significantly engage in vaccination refusal (high potential for action and high interest in conspiracy theories). Recommended communication strategy should emphasize individual profits [51] such as access to specific services and goods. Moderation of discussion in local traditional and social media could be considered for instance in Poznań, the Tricity [52] or in the górnośląskie agglomeration [53].
- Factor 3 - structurally heterogeneous vulnerable regions. Probably a separate strategy should be prepared for the Warsaw metropolitan area and the rest of mazowieckie. As usual, the opolskie Voivodeshipis difficult to classify due to its uniqueness [54].

It is important to mention that the proposed classification has partially revealed the socio-epide-

Table 1. Factor loads estimated with minimum likelihood method (using Statistica 13)

\begin{tabular}{|c|c|c|c|}
\hline \multirow{2}{*}{ voivoideship } & \multicolumn{3}{|c|}{ Factors } \\
\hline & 1 & 2 & 3 \\
\hline wielkopolskie & & 0.68 & \\
\hline $\begin{array}{l}\text { kujawsko- } \\
\text {-pomorskie }\end{array}$ & -0.94 & & \\
\hline małopolskie & -0.84 & & \\
\hline dolnośląskie & -0.95 & & \\
\hline łódzkie & & & -0.40 \\
\hline lubelskie & -0.90 & & \\
\hline lubuskie & -0.96 & & \\
\hline mazowieckie & & & -0.28 \\
\hline opolskie & & & 0.27 \\
\hline podlaskie & -0.86 & & \\
\hline pomorskie & & 0.65 & \\
\hline śląskie & & 0.76 & \\
\hline podkarpackie & -0.78 & & \\
\hline świętokrzyskie & -0.90 & & \\
\hline $\begin{array}{l}\text { warmińsko- } \\
\text {-mazurskie }\end{array}$ & & & 0.34 \\
\hline $\begin{array}{l}\text { zachodnio- } \\
\text { pomorskie }\end{array}$ & -0.93 & & \\
\hline$\%$ Variance expl & 0.73 & 0.15 & 0.04 \\
\hline
\end{tabular}


miological structure of the regions, but a proper mix of qualitative and quantitative studies [55] should be conducted for each administrative unit to extensively explore the composition of subpopulations (Fig. 1) and the socio-epidemiological context (Fig. 2).

The issue of how to convince people to actually take the inoculum is very difficult and it requires the transfer of knowledge about audience profiling and content targeting from marketing research to $\mathrm{pu}$ blic health. We showed that the simple rational and trust/information [41] deficit models alone could not easily explain vaccine hesitancy in Poland. This is just a preliminary and signalling study based on limited empirical data [56] and e.g. keywords selection in defining socio-epidemiological dimensions should be justified as the next step as well as Polish speaking Internet users are only a subset of the entire population. Vaccine discourse in core regions (factor 2), which tends to dominate due to a stronger political and economic position with a well-informed population knowing their civil rights, could be different to peripheral regions (factor 1 ), where counter-Enlightenment cultural and political initiative are more common [27]. However, based on this exploratory research, we can claim that the main responsibility should fall on the regional media and local governments (which on average acquire much higher trust than their national counterparts [57-58]) to prepare their own effective dissemination strategy. Especially during the first wave of COVID-19, local media (at least in dolnośląskie) broadcasted more reliable and less polarized information on coronavirus-related issues [59], in comparison with the nationwide media. Moreover, during the pandemic, central governmental agencies and the main players from the opposition parties are known to distribute fake news and manipulate the public by using sociotechnics, which is probably due to short-term political profits [59-60]. Thus, significant funds and responsibilities should be assigned to 16 voivodeships (NUTS-2) or even better to 380 poviats (NUTS-4) to prepare regional communication strategies in collaboration with local traditional and social journalists. Due to possible inequalities in organizational capital among regions, support from central institutions, think tanks and research centers could be required. Example of misclassification of mazowieckie (Table 1) suggests that even voivodeship could be too heterogeneous and deeper geographical mapping would be preferred (however it could be too difficult for logistical reasons in some less organized counties).
Nevertheless, our approach is only a local adaptation of the main information management pillars concerning COVID-19 vaccine [61-62], such as:

- accurate and timely knowledge transition on actual vaccine effectiveness (on individual and herd level) and safety, which must reach citizens and be understood by them;

- infoveillance of traditional and social media to monitor behavioral attitudes in all parts of the given society (Fig. 2);

- building (e)Health literacy, tailoring advice and messages to address various audiences (Fig. 1);

- controlling and improving knowledge propagation (e.g. fact checking), strategic partnerships should be formed across all local and central stakeholders.

\section{Conclusions}

To conclude, only local authorities and researchers who have the knowledge of their society [63-64] and communities with special needs as elderly [65-67], could deliver information in appropriate form and content [68]. Safe and effective vaccines do not only help the inoculated people (efficacy confirmed in multiple RCT), but their primary role should be stopping the spread of SARS-CoV-2 (if proved in observational studies or clinical trials). The theoretical effect of vaccination seems to be super-linear [69], so higher vaccine coverage could mean ever more QALYs (quality-adjusted life years) saved due to infections in the local population, as long as the proper balance in delivery among essential workers and high-risk groups in the first phase is satisfied. Thus, regionalized marketing could synergize with national $[1,41,70]$ and pan-European [71] evidence-based platforms on benefit-risk disseminations for vaccines and further candidates, while the first person was vaccinated against COVID-19 in Poland on 27 XII 2020.

\section{Acknowledgements}

The authors would like to thank students from the Scientific Circle of Health Promotion at the Wrocław Medical University for coding COVID-19 vaccine-related media releases from Dolnośląskie as well as Karolina Czopek and the NCN (2016/22/E/HS2/00034) from the Warsaw University for the hardware, software licence and sociolingistic support. The dataset is available at: https://ejtcm.gumed.edu.pl/articles/134674 


\section{References}

1. Narodowy Program Szczepień przeciw COVID-19 [in Polish] [Internet]. Ministerstwo Zdrowia. 2020 [cited 2020 Dec 11 ]. p. 1-34. Available from: https://www.gov.pl/attachment/0061e723-fc8c-4f79-8d7b-e33ab58181a8.

2. Adel Ali K, Brolin K, Funke S, Johansen K, Nicolay N, Olsson K, et al. Overview of COVID-19 vaccination strategies and vaccine deployment plans in the EU/EEA and the UK / ECDC Technical Report [Internet]. 2020. Available from: https:// www.ecdc.europa.eu/en/publications-data/overview-current-eu-eea-uk-plans-covid-19-vaccines

3. Lazarus J V, Ratzan SC, Palayew A, Gostin LO, Larson HJ, Rabin K, et al. A global survey of potential acceptance of a COVID-19 vaccine. Nat Med [Internet]. 2021 Feb 20;27(2):225-8. Available from: https://doi.org/10.1038/s41591-020-1124-9

4. Call for Action: Managing the Infodemic. A global movement to promote access to health information and mitigate harm from health misinformation among online and offline communities / WHO [Internet]. 2020 [cited 2020 Dec 11]. Available from: https://www.who.int/news/item/11-12-2020-call-for-action-managing-the-infodemic

5. Stosunek do szczepień przeciw COVID-19 [in Polish] [Internet]. CBOS News. [cited 2021 Apr 21]. Available from: https:// www.cbos.pl/PL/publikacje/news/2020/41/newsletter.php

6. Zygiel A. Sondaż dla RMF FM i 'DGP': Połowa Polaków nie chce szczepić się przeciwko koronawirusowi [in Polish] [Internet]. RMF 24. 2020 [cited 2020 Dec 11]. Available from: https://www.rmf24.pl/raporty/raport-koronawirus-z-chin/ polska/news-sondaz-dla-rmf-fm-i-dgp-polowa-polakow-nie-chce-szczepic-sie,nld, 4861072

7. Morawiecki: za pomocą szczepień 'chcemy osiągnąć jedno' [video in Polish] [Internet]. TVN24; 2020. Available from: https://tvn24.pl/polska/szczepienia-na-covid-19-premier-mateusz-morawiecki-nikogo-nie-bedziemy-zmuszac-do-szczepien-za-ich-pomoca-chcemy-ochronic-przed-wirusem-polakow-4767685

8. Ponad połowa Polaków nie chce zaszczepić się przeciw koronawirusowi Sars-Cov2 [in Polish] [Internet]. ISB Zdrowie. 2020 [cited 2020 Dec 11]. Available from: https://www.isbzdrowie.pl/2020/11/ponad-polowa-polakow-nie-chce-zaszczepic-sie-przeciw-koronawirusowi-sars-cov2/

9. Feleszko W, Lewulis P, Czarnecki A, Waszkiewicz P. Flattening the Curve of COVID-19 Vaccine Rejection - A Global Overview. SSRN Electron J [Internet]. 2020; Available from: $\underline{\text { https://www.ssrn.com/abstract }=3631972}$

10. The State of Vaccine Confidence in the EU: 2018 [Internet]. Vaccine Confidence Project. 2018 [cited 2020 Dec 11]. Available from: https://www.vaccineconfidence.org/research-feed/the-state-of-vaccine-confidence-in-the-eu-2018

11. Jarynowski A, Wójta-Kempa M, Płatek D, Czopek K. Attempt to Understand Public Health Relevant Social Dimensions of COVID-19 Outbreak in Poland. Society Register [Internet], 2020 Apr;4(3):7-44. Available from: https://pressto.amu.edu. $\mathrm{pl} /$ index.php/sr/article/view/22533

12. Boguszewski R, Makowska M, Podkowińska M. A Typology of Poles' Attitudes toward COVID-19 during the First Wave of the Pandemic. Int J Environ Res Public Health [Internet]. 2021 Feb 19;18(4):2002. Available from: https://www.mdpi. com/1660-4601/18/4/2002

13. MacDonald NE, Butler R, Dubé E. Addressing barriers to vaccine acceptance: an overview. Hum Vaccin Immunother [Internet]. 2018 Jan 2;14(1):218-24. Available from: https://doi.org/10.1080/21645515.2017.1394533

14. Brown VJ. Risk Perception: It's Personal. Environ Health Perspect [Internet]. 2014 Oct;122(10). Available from: https:// ehp.niehs.nih.gov/doi/10.1289/ehp.122-A276

15. Kuchar E, Ludwikowska K, Marciniak D, Szenborn L, Nitsch-Osuch A. Public Perception of the Risks Associated with Infectious Diseases in Poland: Ebola and Influenza and Their Impact on the Attitude to Vaccination. In: Pokorski M, editor. Respiratory System Diseases Advances in Experimental Medicine and Biology vol 980 [Internet]. Springer, Cham.; 2017. p. 27-36. Available from: http://link.springer.com/10.1007/5584 2016207

16. Odone A, Ferrari A, Spagnoli F, Visciarelli S, Shefer A, Pasquarella C, et al. Effectiveness of interventions that apply new media to improve vaccine uptake and vaccine coverage. Hum Vaccin Immunother [Internet]. 2015 Jan;11(1):72-82. Available from: http://www.tandfonline.com/doi/abs/10.4161/hv.34313

17. Jarrett C, Wilson R, O'Leary M, Eckersberger E, Larson HJ. Strategies for addressing vaccine hesitancy - A systematic review. Vaccine [Internet]. 2015;33(34):4180-90. Available from: https://www.sciencedirect.com/science/article/pii/ $\underline{\text { s0264410X15005046 }}$

18. Jarynowski A, Wójta-Kempa M, Krzowski Ł. An attempt to optimize human resources allocation based on spatial diversity of COVID-19 cases in Poland. medRxiv [Internet]. 2020 Jan 1;2020.10.14.20090985. Available from: https://www.medrxiv.org/content/10.1101/2020.10.14.20090985v1

19. Rogalski M. COVID-19 w Polsce [in Polish] [Internet]. 2020. Available from: http://bit.ly/covid19-poland

20. Duplaga M. The Determinants of Conspiracy Beliefs Related to the COVID-19 Pandemic in a Nationally Representative Sample of Internet Users. Int J Environ Res Public Health [Internet]. 2020 Oct 26;17(21):7818. Available from: https:// www.mdpi.com/1660-4601/17/21/7818 
21. Furman FM, Zgliczyński WS, Jankowski M, Baran T, Szumowski $\measuredangle$, Pinkas J. The State of Vaccine Confidence in Poland: A 2019 Nationwide Cross-Sectional Survey. Int J Environ Res Public Health [Internet]. 2020 Jun 24;17(12):4565. Available from: https://www.mdpi.com/1660-4601/17/12/4565

22. Kossowska M, Szwed P, Czarnek G. Ideology shapes trust in scientists and attitudes towards vaccines during the COVID-19 pandemic. PsyArxiv [Internet]. 2021 [cited 2021 Apr 21];[preprint]. Available from: https://psyarxiv.com/hcbmw/

23. Włodarska A, Gujski M, Pinkas J, Raciborski F. The influence of socio-demographic characteristics on attitudes towards prophylactic vaccination in Poland. Int J Occup Med Environ Health [Internet]. 2021;34(1):121-32. Available from: https://doi.org/10.13075/ijomeh.1896.01671

24. Jarynowski A. Empiryczne badania społeczne w Polsce istotne dla zdrowia publicznego i epidemiologii w kontekście COVID-19 [in Polish] [Internet]. IBI. 2020 [cited 2021 Apr 21]. Available from: http://interdisciplinary-research.eu/badania-epmiryczne-spoleczne-w-polsce-istotne-dla-zdrowia-publicznego-i-epidemiologii-w-kontekscie-covid-19

25. Jarynowski A, Stochmal M, Maciejewski J. Przegląd i charakterystyka prowadzonych w Polsce badań na temat społecznych uwarunkowań epidemii COVID-19 w jej początkowej fazie [in Polish]. Bezpieczeństwo Obron Socjol [Internet]. 2020;(13/14):38-87. Available from: http://vadda.icm.edu.pl/yadda/element/bwmeta1.element.desklight-a8f411a364a8-4d36-a7d6-c02e1acb8489/c/A Jarynowski M Stochnal J Maciejewski.pdf

26. Krueger T. Epidemia covid-19: Analiza sytuacji biezacej i prognozy krotkoterminowe. 2020. Available from: https://mocos. pl/assets/images/reports/20200513/wroclaw/report wroclaw 20200513.pdf

27. Żuk P, Żuk P, Lisiewicz-Jakubaszko J. The anti-vaccine movement in Poland: The socio-cultural conditions of the opposition to vaccination and threats to public health. Vaccine [Internet]. 2019 Mar;37(11):1491-4. Available from: https:// www.sciencedirect.com/science/article/pii/S0264410X19301586

28. Ganczak M, Kalinowski P, Drozd-Dąbrowska M, Biesiada D, Dubiel P, Topczewska K, et al. School life and influenza immunization: A cross-sectional study on vaccination coverage and influencing determinants among Polish teachers. Vaccine [Internet]. 2020 Jul;38(34):5548-55. Available from: https://www.sciencedirect.com/science/article/pii/ $\underline{\text { S0264410X19314471 }}$

29. Ganczak M, Bielecki K, Drozd-Dąbrowska M, Topczewska K, Biesiada D, Molas-Biesiada A, et al. Vaccination concerns, beliefs and practices among Ukrainian migrants in Poland: a qualitative study. BMC Public Health [Internet]. 2021 Dec 7;21(1):93. Available from: https://doi.org/10.1186/s12889-020-10105-9

30. Kraśnicka J, Krajewska-Kułak E, Klimaszewska K, Cybulski M, Guzowski A, Kowalewska B, et al. Mandatory and recommended vaccinations in Poland in the views of parents. Hum Vaccin Immunother [Internet]. 2018 Dec 2;14(12):2884-93. Available from: https://www.tandfonline.com/doi/full/10.1080/21645515.2018.1496766

31. Lusawa A, Pinkas J, Zgliczyński WS, Mazurek M, Wierzba W. Nieprawdziwe informacje w zakresie szczepień ochronnych jako wyzwanie dla zdrowia publicznego [in Polish]. Zdr Publiczne i Zarządzanie [Internet]. 2019;17(1):40-5. Available from: https://www.ejournals.eu/Zdrowie-Publiczne-i-Zarzadzanie/2019/Tom-17-zeszyt-1/art/15353

32. Cianciara D, Szmigiel A. Posting on „Nie szczepimy („We don't vaccinate”) Internet forum. Przegl Epidemiol [Internet]. 2019;73(1):105-15. Available from: http://www.przeglepidemiol.pzh.gov.pl/files/peissues/PE 12019 calosc NET bez okladki.pdf\#page=105

33. Kołłątaj B, Kołłątaj W, Karwat I, Sobieszczański J, Panasiuk L. Anti-vaccine movements - health care, ignorance or a diversion aimed at destabilizing the health situation? Part 2. Contemporary conditions for the functioning and development of anti-vaccination movements. Ann Agric Environ Med [Internet]. 2020 Dec 22;27(4):553-61. Available from: http:// www.aaem.pl/Anti-vaccine-movements-health-care-ignorance-or-a-diversion-aimed-at-destabilizing, 126014,0,2.html

34. Żuk P, Żuk P. Right-wing populism in Poland and anti-vaccine myths on YouTube: Political and cultural threats to public health. Glob Public Health [Internet]. 2020 Jun 2;15(6):790-804. Available from: https://www.tandfonline.com/doi/full $\angle 10.1080 / 17441692.2020 .1718733$

35. Jaroszewska K, Marciniak A, Gawlak M, Życińska K, Wardyn K, Nitsch-Osuch A. Postrzeganie aktywności ruchów antyszczepionkowych przez rodziców małych dzieci. Postępy Nauk Med [Internet]. 2014;27(9):617-21. Available from: http://31.186.81.235:8080/api/files/view/9236.pdf

36. Kuchar E, Szenborn L. Postawy antyszczepionkowe i możliwości polemiki. Przew Lek GPs [Internet]. 13(5). Available from: https://www.termedia.pl/Postawy-antyszczepionkowe-i-mozliwosci-polemiki,8,15917,0,0.html

37. Kardas P, Zasowska A, Dec J, Stachurska M. Reasons for low influenza vaccination coverage: crosssectional survey in Poland. Croat Med J [Internet]. 2011;52(2):126-33. Available from: https://hrcak.srce.hr/index.php?id clanak jezik=106365\&show=clanak

38. Czajka H, Czajka S, Biłas P, Pałka P, Jędrusik S, Czapkiewicz A. Who or What Influences the Individuals' Decision-Making Process Regarding Vaccinations? Int J Environ Res Public Health [Internet]. 2020 Jun 21;17(12):4461. Available from: https://www.mdpi.com/1660-4601/17/12/4461 
39. Troszyński M, Bieliński J, Bukowska X, Iwińska K, Markowska B, Nowicka M, et al. Czas pandemii w polskich mediach społecznościowych / Collegium Civitas [in Polish] [Internet]. 2020. Available from: https://www.civitas.edu.pl/wp-content/uploads/2020/07/czas pandemii w polskich mediach spolecznosciowych.pdf

40. Krawczyk M, Mikulski K. COVID-19: Dezinformacja w polskiej cyberprzestrzeni / Instytut Kościuszki [in Polish] [Internet]. 2020. Available from: https://ik.org.pl/wp-content/uploads/raport dezinformacja pl v3.pdf

41. Rzymski P, Borkowski L, Drąg M, Flisiak R, Jemielity J, Krajewski J, et al. The Strategies to Support the COVID-19 Vaccination with Evidence-Based Communication and Tackling Misinformation. Vaccines [Internet]. 2021 Feb 1;9(2):109. Available from: https://www.mdpi.com/2076-393X/9/2/109

42. Google Trends [Internet]. [cited 2020 Dec 8]. Available from: https://trends.google.com/trends/?geo=PL

43. Shetty P. Experts concerned about vaccination backlash. Lancet [Internet]. 2010 Mar;375(9719):970-1. Available from: https://linkinghub.elsevier.com/retrieve/pii/S0140673610604217

44. Malinowski B, Redfield R. Magic, science and religion and other essays: Selected, and with an introduction by Robert Redfield. Illinois: The Free Press; 1948.

45. Luz PM, Nadanovsky P, Leask J. How heuristics and cognitive biases affect vaccination decisions. Cad Saude Publica [Internet]. 2020;36(suppl 2). Available from: http://www.scielo.br/scielo.php?script=sci arttext\&pid=S0102-311X2020001405006\&tlng=en

46. Jaka jest liczba uchyleń dotyczących szczepień obowiązkowych? [in Polish] [Internet]. Szczepienia info. 2020 [cited 2020 Dec 11]. Available from: https://szczepienia.pzh.gov.pl/faq/iaka-jest-liczba-uchylen-szczepien-obowiazkowych/

47. Rogalska J, Augustynowicz E, Gzyl A, Stefanoff P. Postawy rodziców wobec szczepień ochronnych w Polsce / Parental attitudes towards childhood immunisations in Poland [in Polish]. Przegl Epidemiol [Internet]. 2010;64(1):91-7. Available from: http://www.ncbi.nIm.nih.gov/pubmed/20499667

48. Jarynowski A. Potencjał protestów w Polsce [in Polish] [Internet]. Infodemia Koronawirusa - Analiza polskiego Internetu. 2020. Available from: http://www.infodemia-koronawirusa.pl/potencjal-protestow-w-polsce/

49. Braczkowska B, Kowalska M, Braczkowski R, Barański K. Determinants of vaccine hesitancy. Prz Epidemiol [Internet]. 2017;71:227-36. Available from: http://www.przeglepidemiol.pzh.gov.pl/files/peissues/PE nr 22017 Caly srodek internet.pdf\#page $=75$

50. Voinson M, Billiard S, Alvergne A. Correction: Beyond Rational Decision-Making: Modelling the Influence of Cognitive Biases on the Dynamics of Vaccination Coverage. PLoS One [Internet]. 2016 Dec 1;11(12):e0167842. Available from: https://dx.plos.org/10.1371/journal.pone.0167842

51. Maliszewski N. How Do People Resolve Conflict Between Implicit and Explicit Attitudes? Polish Psychol Bull [Internet]. 2011 Jan 1;42(1):36-45. Available from: http://journals.pan.pl/dlibra/publication/114612/edition/99665/content

52. Szczupak M, Augustyniak T, Sikorska K. The avoidance of vaccinations among people aged 0-18 years in pomorskie voivodeship in 2000-2017. Przegl Epidemiol [Internet]. 2020;74(1):109-18. Available from: http://www.przeglepidemiol. pzh.gov.pl/pobierz-artykul?id=2309

53. Hubicki L, Czech E, Kowalska M, Zejda JE. Szczepienia ochronne dzieci w rodzinach o różnym stanie społeczno-ekonomicznym w Bytomiu. Prz Epidemiol [Internet]. 2004;58(4):713-23. Available from: http://www.przeglepidemiol.pzh.gov. $\mathrm{pl} / \mathrm{szczepienia-ochronne-dzieci-w-rodzinach-o-roznym-stanie-spoleczno-ekonomicznym-w-bytomiu}$

54. Kisielewicz D. Historyczne uwarunkowania odrębności regionu Śląska Opolskiego [in Polish]. Pogran Polish Borderl Stud [Internet]. 2015;3(1):7-18. Available from: https://depot.ceon.pl/bitstream/handle/123456789/14684/kisielewicz t3n1.pdf? sequence=1\&isAllowed=y

55. Jarynowski A, Paradowski M, Buda A. Modelling communities and populations: An introduction to computational social science. Stud Metodol [Internet]. 2019;(39):123-52. Available from: http://repozytorium.amu.edu.pl:8080/bitstream/10593/25476/1/SM39 MT Cz; Ö\%2B广̌',ç.pdf

56. Szmuda T, Ali S, Özdemir C, Syed MT, Singh A, Hetzger TV, et al. Datasets and future research suggestions concerning the novel Coronavirus (COVID-19). Eur J Transl Clin Med [Internet]. 2020 Dec 3;3(2):80-5. Available from: https://ejtcm. gumed.edu.pl/articles/72

57. Zaufanie społeczne / CBOS [in Polish]. Komun z Badań [Internet]. 2020;(43):1-16. Available from: https://www.cbos.pl/ SPISKOM.POL/2020/K 043 20.PDF

58. Newman N, Fletcher R, Schulz A, Andı S, Nielsen KR. Reuters Institute Digital News Report 2020 [Internet]. 2020. Available from: https://reutersinstitute.politics.ox.ac.uk/sites/default/files/2020-06/DNR 2020 FINAL.pdf

59. Jarynowski A. Monitorowanie percepcji ryzyka Covid-19 na Dolnym Śląsku za pomocą analizy śladu cyfrowego w internecie 15.01-05.08.2020 [in Polish]. Wrocław: Instytut Badań Interdyscyplinarnych; 2020. 
60. Komunikat ICM w związku z informacjami medialnymi dotyczącymi wpływu aktualnie trwających protestów na rozwój epidemii COVID-19 [Internet]. ICM. 2020. Available from: https://icm.edu.pl/blog/2020/11/03/komunikat-icm-zwiazku-informacjami-medialnymi-dotyczacymi-wplywu-aktualnie-trwajacych-protestow-rozwoj-epidemii-covid-19/

61. Eysenbach G. How to Fight an Infodemic: The Four Pillars of Infodemic Management. J Med Internet Res [Internet]. 2020 Jun 29;22(6):e21820. Available from: http://www.jmir.org/2020/6/e21820/

62. Tangcharoensathien V, Calleja N, Nguyen T, Purnat T, D'Agostino M, Garcia-Saiso S, et al. Framework for Managing the COVID-19 Infodemic: Methods and Results of an Online, Crowdsourced WHO Technical Consultation. J Med Internet Res [Internet]. 2020 Jun 26;22(6):e19659. Available from: http://www.jmir.org/2020/6/e19659/

63. Andrzejak R. Zdrowie dla regionu [in Polish]. Wałbrzych: Wydawnictwo Uczelniane Państwowej Wyższej Szkoły Zawodowej im. Angelusa Silesiusa; 2015.

64. Ludwikowska KM, Biela M, Szenborn L. HPV vaccine acceptance and hesitancy - lessons learned during 8 years of regional HPV prophylaxis program in Wroclaw, Poland. Eur J Cancer Prev [Internet]. 2020 Jul 25;29(4):346-9. Available from: https://journals.Iww.com/10.1097/CEJ.0000000000000556

65. Mesjasz J, Skawina I. Współczesne wyzwania gerontologii.Człowiek w pełni - podejście holistyczne [in Polish] [Internet]. Łódź: Społeczna Akademia Nauk; 2019. Available from: http://monografie.san.edu.pl/wp-content/uploads/2020/03/ $\underline{\text { SiM-85.pdf }}$

66. Ganczak M, Gil K, Korzeń M, Bażydło M. Coverage and Influencing Determinants of Influenza Vaccination in Elderly Patients in a Country with a Poor Vaccination Implementation. Int J Environ Res Public Health [Internet]. 2017 Jun 20;14(6):665. Available from: http://www.mdpi.com/1660-4601/14/6/665

67. Nessler K, Krztoń-Królewiecka A, Chmielowiec T, Jarczewska D, Windak A. Determinants of influenza vaccination coverage rates among primary care patients in Krakow, Poland and the surrounding region. Vaccine [Internet]. 2014 Dec;32(52):7122-7. Available from: https://linkinghub.elsevier.com/retrieve/pii/s0264410X14014017

68. Bispo Júnior JP, Morais MB. Participação comunitária no enfretamento da COVID-19: entre o utilitarismo e a justiça social. Cad Saude Publica [Internet]. 2020;36(8). Available from: http://www.scielo.br/scielo.php?script=sci arttext\&pid=S0102-311X2020000803001\&tlng=pt

69. Jarynowski A, Grabowski A. Modelowanie Epidemiologiczne Dedykowane Polsce [in Poland]. Portal CZM [Internet]. 2015;9(6):1-22. Available from: http://www.czm.mif.pg.gda.pl/wp-content/uploads/fam/publ/jarynowski2.pdf

70. Stanowisko 7. zespołu ds. COVID-19 przy Prezesie PAN: Szczepienie jest jedynym racjonalnym wyborem, dzięki któremu będziemy mogli szybciej wyjść z pandemii [in Poland] [Internet]. 2020 [cited 2012 Dec 11]. Available from: https:// informacje.pan.pl/index.php/informacje/materialy-dla-prasy/3210-stanowisko-7-zespolu-ds-covid-19-przy-prezesie-pan-szczepienie-jest-jedynym-racjonalnym-wyborem-dzieki-ktoremu-bedziemy-mogli-szybciej-wyjsc-z-pandemii

71. Sturkenboom M, Bahri P, Chiucchiuini A, Grove Krause T, Hahné S, Khromava A, et al. Why we need more collaboration in Europe to enhance post-marketing surveillance of vaccines. Vaccine [Internet]. 2020 Dec;38:B1-7. Available from: https://linkinghub.elsevier.com/retrieve/pii/S0264410X19310023 